\title{
Reduction of Postharvest Loss and Prolong the Shelf-Life of Banana through Hot Water Treatment
}

\author{
Md. Nurul Amin \\ Senior Scientific Officer, Farm Machinery and Postharvest Process Engineering Division \\ Bangladesh Agricultural Research Institute, Joydebpur, Gazipur \\ Md. Mosharraf Hossain \\ Professor, Farm Power and Machinery \\ Bangladesh Agricultural University, Mymensingh
}

\begin{abstract}
For reducing the post-harvest loss and extension of shelf-life of banana, it is treated with fungicide or combination of fungicide and hot-water treatment. A study was conducted for developing a method to control post-harvest diseases and extension of shelf-life of banana through non-chemical method of hot water treatment. The best treatment combination was found at $53{ }^{\circ} \mathrm{C}$ for 9 minutes. Shelf-lives of BARI Kola 1 and Sabri Kola treated with hot water increased by 26 and $27.5 \%$, respectively against untreated fruits. Post-harvest loss (decay and crown rot) of these varieties was reduced, respectively by $95 \%$ and $70 \%$ against untreated fruits. Firmness of treated fruits for both varieties was found higher than that of untreated fruits during ripening. Total soluble solid, total sugar, acidity and $\beta$-carotene of treated fruits of these varieties increased over untreated fruits. The $\mathrm{pH}$ and vitamin $C$ of treated bananas decreased over untreated fruits during ripening.
\end{abstract}

\section{Introduction}

Banana (Musa sapientum0 L) is one of the important tropical fruits, with a global annual production of about 102 million metric tonnes in which Asia contributes to 63 million tonnes ${ }^{1}$. Bangladesh produces 4.22 million tonnes of fruits annually from 0.15 million hectares of land. Of these, mango, banana, jackfruit, pineapple, papaya, litchi and guava are the major fruits. Among the fruits, banana ranks first in terms of area coverage (0.06 million hectare) and second in terms of production (0.82 million tonnes) in Bangladesh².

Banana is a staple food of many people of the tropical countries. The ripe fruit contains many of the elements that are essential for a balanced diet. Banana contains fat, natural sugars, protein, potassium and vitamins A, B complex and C. A ripe banana is easily digested and it imparts quick energy. Banana can also be used as medicinal fruit. It helps recover anaemia, blood pressure, brain power, constipation, depression, hangovers, ulcer etc ${ }^{3}$. Malnutrition and under-nutrition have now become an alarming problem of the people of the developing countries affecting their economic and physical development. Protein-energy, nutrition and vitamin deficiencies are the most serious nutritional disorders in low income groups. Due to these deficiencies, under-weights and high mortality are prevalent in pre-school children and infants. The minimum dietary requirement of fruit per day per person is $115 \mathrm{~g}$, whereas our availability is only $30-35 \mathrm{~g}^{4}$. Per capita availability of fruits is further reduced sometimes due to high level of postharvest losses ${ }^{5}$. Postharvest losses can be reduced considerably by

\footnotetext{
*Corresponding Author: Md. Nurul Amin

E-mail: naminbari@gmail.com
}

improving storage technology and prolonging the shelflife of fruits.

In developed country, like USA, postharvest losses of fruit are significant and go up to $20 \%{ }^{6}$. These losses not only comprise the nutrition losses but also land cultivation, energy (fuel, machinery), fertilizers, chemical, irrigation water and labour losses. The increase in yield and productivity is lagging significantly behind the increase in world population, and the nutritional need for the world. Therefore, reduction in postharvest losses should be considered as a strategic requirement all over the world, especially in developing countries. The increase in yield and productivity, without reducing postharvest losses, will not be sufficient in securing the availability of food in the world.

Chemicals have been widely used to reduce the incidence of postharvest diseases. Although it is effective, this method is discouraged or even discarded in recent years due to economic, environment and health concerns. The longer shelf-life and less postharvest diseases of banana are needed to export in aboard and store for marketing in super market at different distance place. Interest in heat treatments waned with the development of chemical fumigants, which could be applied cheaply and easily. Today, with the increasing cost of developing new chemicals and regulatory restrictions on existing ones, interest in heat disinfestations has been revived ${ }^{7}$.

Heat treatment technology is relatively simple and non chemical alternative that can kill quarantine pests (insect and fungi) of perishable commodities. Hot-water 
treatment also increases the shelf-life of banana and develop attractive colour. For this purpose this study is essential to minimize the problems of exportation and storage for marketing.

\section{Methodology}

Bunches of properly matured bananas of BARI Kola 1 and Sabri Kola were harvested from experimental field of Farm Machinery and Postharvest Process Engineering Division carefully. Second and third hands of each bunch were selected to conduct the experiment and four fingers of uniform size and shape were taken for each replication having three replications of each treatment. They were washed in fresh water to remove dirt and latex. These fruits were treated in hot water using the developed hot-water plant for respective exposure time and temperature. The treated fruits were dried quickly by an electric fan and kept on a wooden table for study at room temperature. During experiment, room temperature and humidity were recorded.

Weight, shelf-life, decay and crown rot of banana fruits of each treatment were measured. Firmness, colour, TSS, $\mathrm{pH}$, titratable acid, total sugar, vitamin $\mathrm{C}$ and $\beta$ carotene of banana fruits were also determined on the basis of the highest shelf-life of treatments among the different treatment combinations of temperature and exposure time.

Fruit firmness were measured using digital firmness tester (DFT 14, made in France by Agro-technologie) equipped with $8 \mathrm{~mm}$ cylindrical stainless probes. The peel colour of fruit was measured using a chroma meter (CR-400, Konica Minolta Sensing Inc., Japan). An 8 $\mathrm{mm}$ diameter measuring head mounted on the meter was calibrated each time with a standard white plate. Colour measurements were recorded using Hunter L*, $\mathrm{a}^{*}$ and $\mathrm{b}^{*}$ scale $^{8,9}$. Ascorbic acid was determined according to the dye method ${ }^{10}$. $\beta$-carotene of fruits pulp measured by $\mathrm{AOAC}^{11}$.

\section{Experimental Design and Statistical Analysis}

The experiments were arranged in a complete randomized design (CRD) with 3 replicates using 12 fruits for each treatment.

\section{Varieties}

$\mathrm{V}_{1}=$ Optimum matured (120 DAES) BARI Kola 1

$\mathrm{V}_{2}=$ Optimum matured (100 DAES) Sabri Kola

\section{Hot water treatments}

$\mathrm{T}_{1}=$ Bananas are treated at $47{ }^{\circ} \mathrm{C}$ for $3-21 \mathrm{~min}$ at 2 minutes intervals
$\mathrm{T}_{2}=$ Bananas are treated at $49{ }^{\circ} \mathrm{C}$ for $3-19 \mathrm{~min}$ at 2 minutes intervals

$\mathrm{T}_{3}=$ Bananas are treated at $51{ }^{\circ} \mathrm{C}$ for $3-17 \mathrm{~min}$ at 2 minutes intervals

$\mathrm{T}_{4}=$ Bananas are treated at $53^{\circ} \mathrm{C}$ for $3-9$ min at 2 minutes intervals

$\mathrm{T}_{5}=$ Bananas are treated at $55{ }^{\circ} \mathrm{C}$ for $3-9$ min at 2 minutes intervals

$\mathrm{T}_{6}=$ Bananas are treated at $57{ }^{\circ} \mathrm{C}$ for 3-9 min at 2 minutes intervals

$\mathrm{T}_{7}=$ Control (untreated bananas and kept at room temperature)

\section{Statistical analysis:}

Data were statistically analyzed using SPSS software version 13 by analysis of variance and significant differences among the treatments were determined using Duncan's Multiple Range Test at $\mathrm{P} \leq 0.05$.

\section{Results \& Discussion}

\section{Total weight loss}

Weight loss of BARI Kola 1 and Sabri Kola at $47{ }^{\circ} \mathrm{C}$ for different exposure time is shown in Fig. $1 \& 2$. The weight losses of BARI Kola 1 and Sabri Kola at different temperature treatments increased gradually with the increase of exposure period. It was also observed that there was a strong linear relationship between weight loss and exposure times. At $57^{\circ} \mathrm{C}$ for 7 to 9 minutes, weight losses of fruits both varieties were drastically increased with the increase of exposure time (Fig. 3 \& 4). It might be damaged due to burning the tissue of fruit surface. Furthermore, the weight losses of treated bananas were higher than that of untreated fruits. It occurred owing to hot water treatment that caused the acceleration of evaporation rate from the fruit surface. The lowest and the highest weight losses of BARI Kola 1 and Sabri Kola were found to be 10.20 to $13.88 \%$ at $47{ }^{\circ} \mathrm{C}$ for 3 minute and 21 minutes, respectively. Therefore, higher loss of fruits was observed in BARI Kola 1 than that of fruit in Sabri Kola due to varietal effect. Similar results were obtained for other treatments.

\section{Shelf-life}

Shelf-life of BARI Kola 1 and Sabri Kola increased gradually with the increase of exposure period (Fig. 1 \& 2). Similar trend was found in other treatments except treatment of $57{ }^{\circ} \mathrm{C}$ for both varieties. The shelf-life of fruit reduced drastically in treatment of $57{ }^{\circ} \mathrm{C}$ due to higher water temperature which caused burning of the skin and damage of the fruit tissues (Fig. $3 \& 4$ ). Linear and two degree polynomial relationship between shelflife and exposure time were found. The highest shelflife of BARI Kola 1 and Sabri Kola was found to be 
10.5 and 10.83 days at $53{ }^{\circ} \mathrm{C}$ for 9 min against 7.83 and 8.17 days of untreated fruit, respectively. On the other hand, the second highest shelf-life of these varieties was found to be at $55^{\circ} \mathrm{C}$ for 5 or 7 minutes. Statistically significant differences were noticed among the treatments. Hot water treatment perhaps retarded the physiological and biological activities and finally led to the longest shelf-life. Banana fruits dipped in hot water (45 ${ }^{\circ} \mathrm{C}$ for 15 minutes or $50{ }^{\circ} \mathrm{C}$ for 10 minutes) extended the shelf-life ${ }^{12}$.

\section{Decay}

From Fig.s $1 \& 2$, decay percentage of fruits of BARI Kola 1 and Sabri Kola decreased sharply with the increase of exposure time. But the decay percentage of fruits increased drastically with the increased of exposure time at $57{ }^{\circ} \mathrm{C}$ (Fig. $3 \& 4$ ). The regression equation expressed that there is linear relation and two degree polynomial between the decay and exposure time against treated treatments. The variation decay of treated and untreated fruits was observed significant. The lowest decay of treated fruits of both varieties was observed zero in treatments of $47{ }^{\circ} \mathrm{C}$ for 19 and 21 minutes, $49{ }^{\circ} \mathrm{C}$ for 17 minutes, $51^{\circ} \mathrm{C}$ for 11,13 , and 15 minutes, $53{ }^{\circ} \mathrm{C}$ for 9 minutes, $55{ }^{\circ} \mathrm{C}$ for 5 and 7 minutes, $57^{\circ} \mathrm{C}$ for 3 minutes. Dipping bananas in water at 47 to $52{ }^{\circ} \mathrm{C}$ effectively inhibited anthracnose and finger rot development when fruits were artificially infected $^{13}$.

\section{Crown rot}

Crown rot of fruits was investigated for different exposure time. Decreasing tendency of crown rot was noticed with the advancement of treating duration (Fig.
$1 \& 2$ ). From the regression equation, a strong linear relation was found among the treated treatments. A highly significant difference was observed among the treated and untreated treatments. It was revealed that crown rot increased sharply with the increase of exposure time at $57^{\circ} \mathrm{C}$ (Fig. $3 \&$ 4). The lowest crown rot $(26.67 \%)$ occurred at $57{ }^{\circ} \mathrm{C}$ in both the varieties. Furthermore, the crown rot percentage of treated bananas was lower than that of untreated fruits owing to combined effect of treating temperature and exposure time. Minimum bruising and controlled crown rot of bananas was achieved by hot water at $50{ }^{\circ} \mathrm{C}$ for 5 minutes $^{14}$.

\section{Firmness}

Fruit firmness decreased with storage at a faster rate in the untreated fruits than hot water treated fruit (Table 1 and 2). Firmness of treated banana of BARI Kolal and Sabri Kola in $53{ }^{\circ} \mathrm{C}$ for 9 minutes had significant higher against other treatments but similar to treatment of 55 ${ }^{\circ} \mathrm{c}$ for $7 \mathrm{~min}$. Furthermore, higher firmness of fruit was found in Sabri Kola than that of BARI Kola 1.

Softening of fruits is related to a change in cell wall component and starch degradation ${ }^{15}$. The starch granules, packed in the tissue of banana flesh give rise to the toughness of the unripe fruit, and are hydrolyzed to sugar while an increase of the cell wall solubility allows water and nutrients to pass in and out of the cells. Fruit firmness decreased steadily during the full ripening stage. It might be occurred that during those periods all starch would be completely converted to sugar. A similar trend was found by Siriboon and Banlusilp $^{16}$.

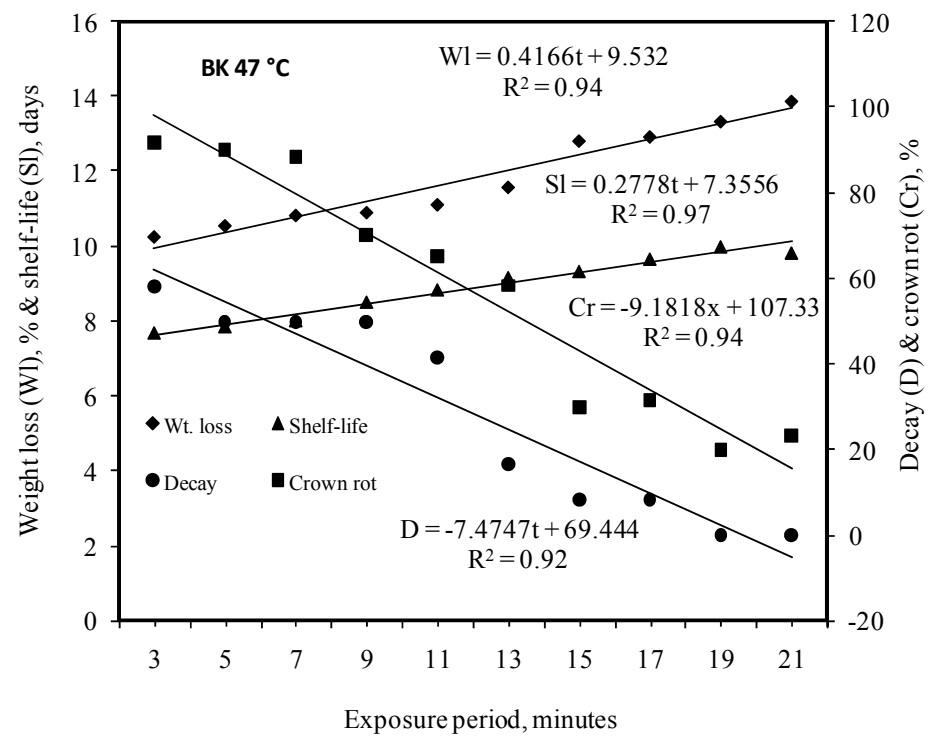

Fig.1.Weight loss, shelf-life, decay and crown rot of BARI Kola 1 at $47^{\circ} \mathrm{C}$ for different exposure period 


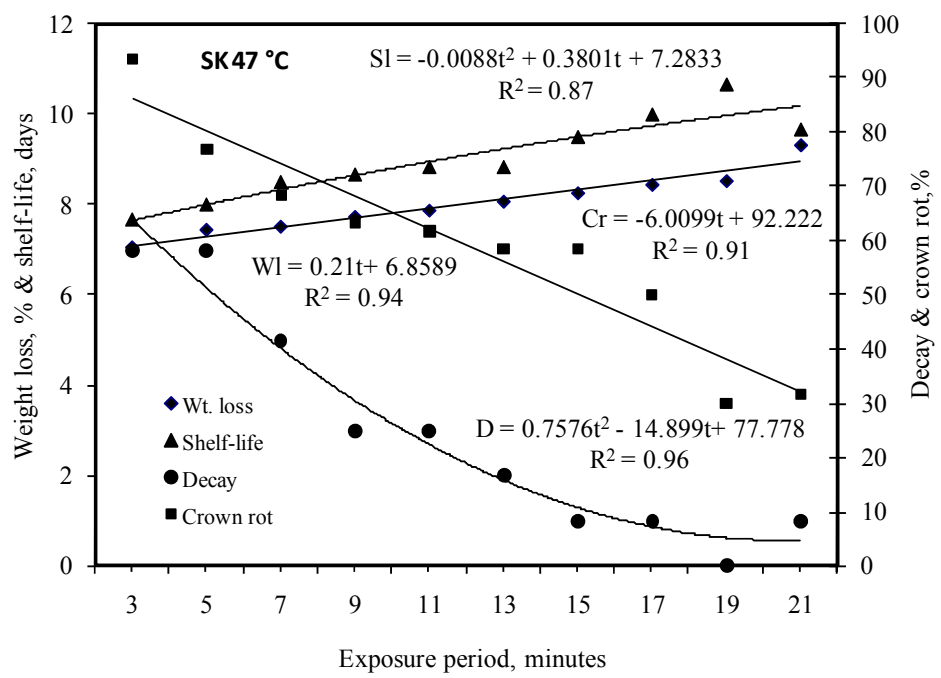

Fig. 2. Weight loss, shelf-life, decay and crown rot of Sabri Kola at $47^{\circ} \mathrm{C}$ for different exposure period

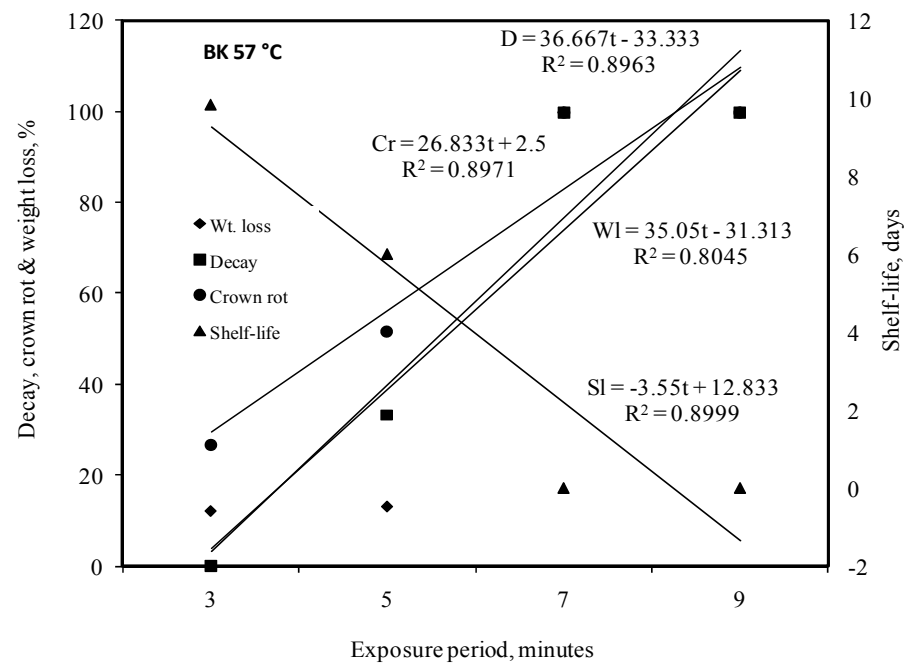

Fig. 3 Weight loss, shelf-life, decay and crown rot of BARI Kola 1 at $57^{\circ} \mathrm{C}$ for different exposure period

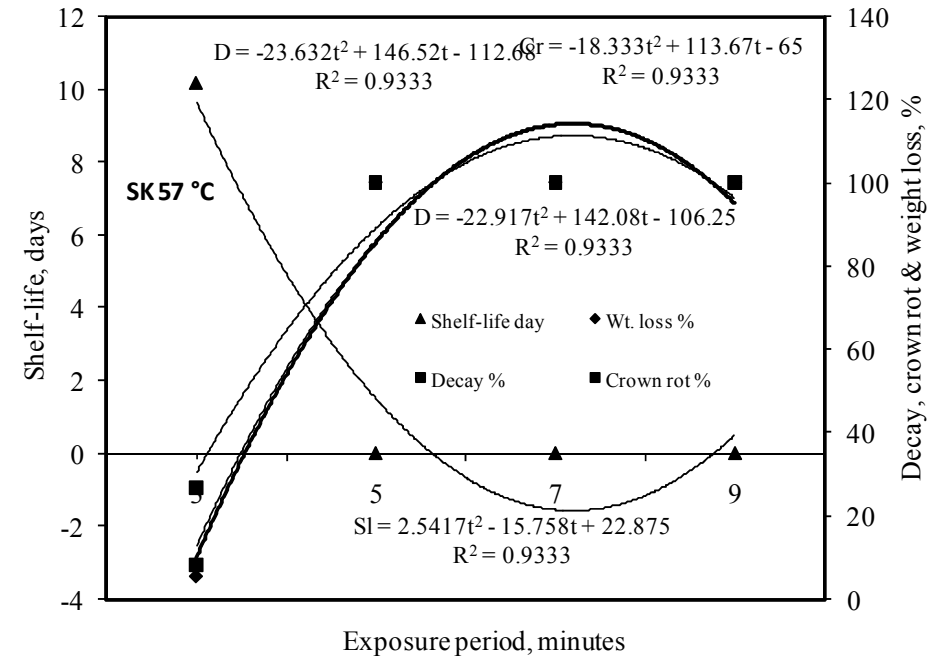

Fig. 4 Weight loss, shelf-life, decay and crown rot of Sabri Kola at $57^{\circ} \mathrm{C}$ for different exposure period 


\section{Colour}

Brightness $\left(\mathrm{L}^{*}\right)$ of treated and untreated fruits increased gradually whereas hue angle $\left(\mathrm{h}^{\circ}\right)$ of these treatments decreased during ripening period (Table 1 and 2). Brightness $\left(\mathrm{L}^{*}\right)$ and hue angle $\left(\mathrm{h}^{\circ}\right)$ of treated fruits was higher than that of untreated fruits because of hot water treatment effect. The use of hot-water treatment to suppress microbial development and spoilage also promoted retention of firmness characteristics. Significant difference of lightness $\left(\mathrm{L}^{*}\right)$ was observed in $53{ }^{\circ} \mathrm{C}$ for 9 min than other treatments. The $\mathrm{h}^{\circ}$ of treatment at $55{ }^{\circ} \mathrm{C}$ for 7 minutes was significantly higher than that of untreated fruits and to treatment at $49^{\circ} \mathrm{C}$ for $17 \mathrm{~min}$ but it was similar to others. Moreover, Sabri Kola was brightner and yellower than BARI Koal 1 due to higher value of $\mathrm{L}^{*}$ and lower value of $\mathrm{h}^{\circ}$, respectively. Similar results were reported by Hassan $^{17,18}$

\section{Total Soluble Solid, Titratable acid and pH}

Total soluble solid and titratable acid of treated and untreated fruits increased whereas $\mathrm{pH}$ of fruit decreased gradually during ripening period. Acid and $\mathrm{pH}$ of treated fruits were more or less same as untreated fruits but TSS was higher than that of untreated fruits. Significant difference of TSS of BARI Kola 1 was higher than that of Sabri Kola resulting sweeter than that (Table 1 and 2). According to Seymour ${ }^{15}$, in banana pulp, the total amount of acid increased during ripening; the main acids being malic, citric and oxalic. While the first two acids were responsible for tartness in the unripe banana, the oxalic acid contributed to astringent taste of the fruit. A similar trend was reported by Siriboon and Banlusilp ${ }^{16}$.

\section{Vitamin C}

Vitamin C content of these treatments decreased gradually in all the varieties as they proceeded towards ripening and senescence. The reduction in vitamin $\mathrm{C}$ contents during ripening might be attributed to the oxidation of ascorbic acid as ripening proceeded ${ }^{20}$. In the untreated fruits vitamin $\mathrm{C}$ content was higher than those of the treated bananas throughout the ripening stages. In control (untreated) treatment, senescence took place earlier and vitamin $\mathrm{C}$ was perhaps not fully oxidized leading to maximum vitamin $\mathrm{C}$ content at full ripening stage.

\section{Sugar}

Total sugars of treated and untreated fruits of both varieties increased during ripening. The highest total sugar contents of fruits treated at $53^{\circ} \mathrm{C}$ for 9 minutes for both the varieties followed by other treatments (Table 1 and 2). The total sugar content was greatly influenced by hot water treatment. The increase in total sugar associated with ripening was due to the breakdown of polysaccharides, and conversion of starch into sugars ${ }^{19}$.

Table 1. Effect of temperature and exposure time on some physico-chemical parameters of BARI Kolal duringstorage at ambient temperature $\left(32.2^{\circ} \mathrm{C}\right)$

\begin{tabular}{c|c|c|c|c|c}
\hline \multirow{2}{*}{ Treatment } & \multirow{2}{*}{$\begin{array}{c}\text { Firmness } \\
\mathrm{kg}_{\mathrm{f} m m^{-2}}\end{array}$} & \multicolumn{2}{|c|}{ Colour } & \multirow{2}{*}{$\begin{array}{c}\text { TSS } \\
\text { Brix }(\%)\end{array}$} & $\begin{array}{c}\text { Total sugar } \\
\%\end{array}$ \\
\cline { 3 - 4 } & $0.12 \mathrm{c}$ & $57.99 \mathrm{ab}$ & $90.99 \mathrm{abc}$ & $25.17 \mathrm{a}$ & $18.38 \mathrm{c}$ \\
$\mathrm{T}_{1}$ & $0.12 \mathrm{c}$ & $58.04 \mathrm{ab}$ & $91.30 \mathrm{ab}$ & $25.07 \mathrm{ab}$ & $19.31 \mathrm{ab}$ \\
$\mathrm{T}_{2}$ & $0.12 \mathrm{c}$ & $58.33 \mathrm{ab}$ & $90.41 \mathrm{bc}$ & $25.00 \mathrm{abc}$ & $17.09 \mathrm{e}$ \\
$\mathrm{T}_{3}$ & $0.13 \mathrm{a}$ & $58.46 \mathrm{a}$ & $90.4 \mathrm{bc}$ & $25.20 \mathrm{a}$ & $19.78 \mathrm{a}$ \\
$\mathrm{T}_{4}$ & $0.13 \mathrm{ab}$ & $57.12 \mathrm{~b}$ & $90.34 \mathrm{c}$ & $24.90 \mathrm{abc}$ & $18.98 \mathrm{~b}$ \\
$\mathrm{~T}_{5}$ & $0.12 \mathrm{bc}$ & $58.07 \mathrm{ab}$ & $90.71 \mathrm{abc}$ & $24.63 \mathrm{bc}$ & $17.98 \mathrm{~cd}$ \\
$\mathrm{~T}_{6}$ & $0.12 \mathrm{c}$ & $54.18 \mathrm{c}$ & $91.48 \mathrm{a}$ & $24.53 \mathrm{c}$ & $17.67 \mathrm{~d}$ \\
$\mathrm{~T}_{7}$ & & &
\end{tabular}

Table 2: Effect of temperature and exposure time on some physico-chemical parameters of Sabri Kola during storage at ambient temperature $\left(32.2^{\circ} \mathrm{C}\right)$

\begin{tabular}{|c|c|c|c|c|c|}
\hline \multirow{2}{*}{ Treatment } & \multirow{2}{*}{$\begin{array}{l}\text { Firmness } \\
\mathrm{kg}_{\mathrm{f}} \mathrm{mm}^{-2}\end{array}$} & \multicolumn{2}{|c|}{ Colour } & \multirow{2}{*}{$\begin{array}{c}\text { TSS } \\
\text { Brix (\%) }\end{array}$} & \multirow{2}{*}{$\begin{array}{c}\text { Total } \\
\text { sugar } \\
\%\end{array}$} \\
\hline & & $\mathrm{L}^{*}$ & $\mathrm{~h}^{\circ}$ & & \\
\hline $\mathrm{T}_{1}$ & $1.27 b c$ & $62.39 \mathrm{c}$ & 92.04ab & $23.76 \mathrm{a}$ & 19.10ab \\
\hline $\mathrm{T}_{2}$ & $1.23 \mathrm{~cd}$ & $60.68 \mathrm{~d}$ & $91.50 \mathrm{~b}$ & $21.78 b$ & 19.10ab \\
\hline $\mathrm{T}_{3}$ & $1.17 \mathrm{~d}$ & $62.90 \mathrm{bc}$ & $91.47 \mathrm{~b}$ & $19.84 \mathrm{c}$ & $18.57 \mathrm{c}$ \\
\hline $\mathrm{T}_{4}$ & $1.37 \mathrm{a}$ & $64.43 \mathrm{a}$ & $90.31 \mathrm{c}$ & $24.20 \mathrm{a}$ & $19.23 \mathrm{a}$ \\
\hline $\mathrm{T}_{5}$ & $1.34 \mathrm{ab}$ & $63.91 \mathrm{ab}$ & $90.99 \mathrm{bc}$ & $22.01 \mathrm{~b}$ & 19.17ab \\
\hline $\mathrm{T}_{6}$ & $1.27 \mathrm{bc}$ & $60.76 \mathrm{~d}$ & $92.54 \mathrm{a}$ & $22.23 b$ & $19.03 b$ \\
\hline $\mathrm{T}_{7}$ & $1.19 \mathrm{~cd}$ & $54.32 \mathrm{e}$ & $92.72 \mathrm{a}$ & $19.05 \mathrm{~d}$ & $18.57 \mathrm{c}$ \\
\hline
\end{tabular}




\section{$\beta$-carotene}

$\beta$-carotene of treated and untreated fruits of BARI Kola1 and Sabri Kola increased during ripening period. $\beta$ carotene of treated fruits of BARI Kolal and Sabri Kola was higher than that of untreated fruits. The results indicated that all the treated treatments raised the amount of $\beta$-carotene content over the untreated ones. This might be due to the fact that hot water treatment favoured translocation of carotenoid from the peel to the pulp and resulted in higher $\beta$-carotene content in the treated bananas.

\section{Conclusion}

Decay and crown rot of treated fruits were significantly reduced through hot water treatment. Shelf-life of bananas increased and post-harvest losses of fruits reduced significantly through hot water treatment at 53 ${ }^{\circ} \mathrm{C}$ for 9 minutes or $55{ }^{\circ} \mathrm{C}$ for 7 minutes. Shelf-life of treated banana increased significantly than that of untreated fruits. Brightness and yellowness of banana surface were observed to be more than that of untreated fruits. More firmness and attractive colour of fruit were found for treated Sabri Kola than treated BARI Kola 1. Total soluble solid, total sugar and $\beta$-carotene of treated fruits increased whereas $\mathrm{pH}$ and titratable acid of the same fruits decreased gradually during ripening. Awareness of users may be created through mass media on hot water treatment of banana and other fruits like mango to reduce the postharvest loss and the use of harmful chemicals.

\section{References}

1. F.A.O. (2010), Statistics web site http://www. fao.org, accessed on 04/10/2012.

2. BBS (Bangladesh Bureau of Statistics). (2010), Statistical Yearbook of Bangladesh, Bureau of Statistics, Ministry of Planning, Government of the People's Republic of Bangladesh, Dhaka.

3. CCIN.

http://www.banana.com/medicinal.html viewed 24 July, 2010,

4. Siddiqui, A. B. and Scanlan, F. M. (1995), Nutritives values of fruits, In: Fruit Production Manual, Hort. Res. Div. Project. (FAO/UNDP/ADB Project:BGD/87/025), pp. 1286

5. Mondal, M. F., Rahman, M. A. and Pramanik, M. A. J. (1995), Effect of different postharvest treatments on physico-chemical changes and shelflife of mango, Bangladesh Hort., 23(1\&2):1-5.
6. Yahia, E. M. and Ait-Oubahou, A. (2001), Training manual on postharvest physiology, technology and handling of horticltural crops, BARI, Agricultural Research Management (ARMP-TA).IDA Credit \#2815-BD, Dhaka.

7. Couey, H. M. (1989), Heat treatment for control of postharvest diseases and insect pests of fruits, Horticulture Science, 24:198-202.

8. Hunter, R. S. (1975), The measurement of appearance, Wiley, New York.

9. Francis, F. J. (1980), Colour quality evaluation of horticultural crops, Hort. Sci., 15:58-59.

10. Ranganna, S. (1986), Handbook of Analysis and Quality Control for Fruits and Vegetables, Tata McGraw-Hill Ltd., New Delhi, India, p. 1112.

11. AOAC(Association of Official Agricultural Chemists) (1990), Official Methods of Analysis. Washington, D. C.

12. Varit, S. and Songsin, P. (2011), Effects of hot water treatments on the physiology and quality of 'Kluai Khai' banana, International Food Research Journal, 18(3):1013-1016.

13. Acedo, A. L., Benetiz, M. M. and Millan, L. A. (2001), Heat treatment effect of ripening and disease infection of Philippine bananas and mangoes, Acta Hort., 553:417-419.

14. Kader, A. A. (2005), Post-harvest Technology Research Information Centre, UCDAVIS.

15. Seymour, G. B. (1993), Banana. In: Biochemistry of fruit ripening. Edited by G B Seymour, J E Taylor and G A Tucker, $1^{\text {st }}$ ed. Chapman and Hall, London, pp. 83-101.

16. Siriboon, N. and Banlusilp, P. (2004), Study on the ripening process of "Namwa" banana, Annual Journal of Technology, 7(4):159-164.

17. Hassan, M. K. (2000), Studies on the postharvest behaviour of bananas, MAppSci Thesis, James Cook University, Townsville.

18. Matook, M. S. and Fumio, H. (2004), Effect of heat, calcium chloride and modified atmosphere on the shelf life of banana fruits, Food Preservation Science, 30(4):179-184.

19. Wills, R. H. H., McGlasson, W. B., Graham, D., Lee, T. H. and Hall, E. G. (1989), Post-harvest: An introduction to the physiology and handling of fruits and vegetables. An AVI Book, Van Nostrand Reinhold, New York, 173.

20. Mondal, M. F., Hassan, M. K. and Hoque, M. S. (1998), Physico-chemical changes and shelf-life of mango as influenced by post-harvest treatments, Prog. Agric., 9(1\&2):77-82 